\title{
The Most Used Forms and Methods of Citizens Involvement in Terrorist and Extremist Activity
}

\author{
Danekenova A. ${ }^{1}$, Zhussupova G. ${ }^{1}$, Nurmagambetov R. ${ }^{2}$, Shunayeva S. ${ }^{1}$ \& Popov V. ${ }^{1}$ \\ ${ }^{1}$ Kostanay State University named after A. Baitursynov, Kazakhstan \\ ${ }^{2}$ Kostanay branch, South Ural State University, Russia \\ Correspondence: Danekenova A., Kostanay State University named after A. Baitursynov, Kazakhstan. E-mail: \\ a.tytykalo07@gmail.com
}

Received: June 13, 2019

Accepted: July 9, 2019 Online Published: July 10, 2019

doi:10.5539/jpl.v12n3p1

URL: https://doi.org/10.5539/jpl.v12n3p1

\begin{abstract}
The article analyzes development features of terrorist and extremist activity in the world, as well as in the Republic of Kazakhstan in particular. Authors focus on problems, which have arisen in connection with the emergence of terrorist and extremist activity, and also on the ways of it decision. The article raises one of the large international terrorist organizations - "DAESH", which recruited people from around the world. Authors completely open methods of propaganda and recruitment of people of this organization. The special importance in prevention is allocated for public authorities, realizing confessional policy.
\end{abstract}

Keywords: terrorist activity, recruitment, terrorist organization "DAESH", radical influences, religious terrorism

\section{Introduction}

Currently, there is one of the most complicated problems of world science and practice - a comprehensive study of the concept of terrorism and the reasons for involving people in terrorist activities. It is noteworthy that the activity of religious extremism is increasingly involving mainly young people.

The key role in the decision to join the organization is played by the friendly and family ties between extremists. The typical scenario of joining the Islamic Jihad movement involves several stages. At the initial stage, a young man who feels lonely in a world alien to him is sent to a place he has known even from his homeland life - the mosque - first of all in order to find himself in a circle of familiar people with similar interests. At the second stage, a young person is involved in one of the small groups of like-minded people and the meetings are transferred from religious and cultural institutions to private apartments. At the third stage, an intensive ideological treatment of future extremists takes place (Kardan, 2014). Whatever the initial reasons for joining an extremist network, future extremists undergo lengthy ideological training in small groups, where a feeling of mutual trust and loyalty is formed between the group members, and all members of the group accept the beliefs of their extremist-minded and fanatical leaders.

The new social circle combined with Islamist propaganda alienates religious extremists from friends and family, increasing isolation from society and loyalty to the new group, which in turn strengthens the faith of the new adept in the ideas of Islamic terror (Tarchokov \& Shhagapsoev, 2014a).

At this stage, the members of the cell are ready to take full part in jihad. The critical factor is that they identify the idea of jihad not with abstract postulates of Islamist ideology, but with specific people from the group in which they were trained. No matter how strange this may be, but Islamic Jihad as a whole does not include a separate unit that would recruit new members.

Unlike the usual pattern, when recruiting is top-down, that is, higher-level executives claim lower-level staff, Islamic jihad is built upward - the staff expands under pressure from a large number of young people who want to join movement.

This is evidenced by the fact that so far there has not been a single case of detention of an activist who was engaged in the purposeful recruitment of new supporters. Analysis of financial flows serving the international Islamist terrorist movement also indicates a lack of funding personnel departments or large-scale programs to promote their views among potential supporters (Tarchokov \& Shhagapsoev, 2014a). In the study, in our research, 
we base ourselves on the definition of terrorism, which is given in the Federal Law of the Russian Federation of March 6, 2006 No. 35-FL, where terrorism is considered as "the ideology of violence and the practice of influencing decision-making by state authorities, local governments or international organizations related to the intimidation of the population and (or) other forms of unlawful acts of violence".

There are objective conditions and subjective reasons contributing to a surge in terrorist activities in society. The objective condition for the growth of terrorist activity in our country was the complex processes of political, economic and social order associated with the transformation of the Russian state, with the processes of globalization and information confrontations in the world (Shhagapsoev, \& Tarchokov, 2012). The group of foreign policy conditions is connected with the fact of financing Russian terrorists by a number of foreign non-governmental organizations and funds and the insufficient struggle of foreign special services against this phenomenon. Accordingly, when they enter Russia, this money is spent on the propaganda of terrorism and the recruitment of new members. The overlapping of these channels is an important aspect of preventing citizens from engaging in terrorist activities. One of the reasons for increased terrorist activity is internal political processes in certain regions, connected not only with terrorist opposition to the federal center, but also with the internal struggle of local elites and clans. Such reasons and conditions very actively contribute to the involvement of citizens in terrorist activities on one of the parties (Tarchokov, 2014b).

It should be noted that the modernity of the regional economy and industry associated with an educated and skilled labor force serves as a preventive barrier against the propaganda of terrorism and other extremist and radical ideas, and the archaic nature of the regional economy and industry provokes the population to engage in terrorist activities.

Religious and religious reasons and conditions that promote the involvement of citizens in terrorist activities are among the most powerful and directly active. There is a clear tendency to strengthen precisely the religious, rather than the national separatist type of terrorism and the number of victims is much more during religiously motivated acts of terrorism. Territorial and regional causes and conditions that facilitate the involvement of Russian citizens in terrorist activities are mainly considered by us as a regional aspect of all other types of our classification. Corruption, low level of state administration and weak feedback from the population to local authorities are all-Russian problems. A key issue among psychologists investigating the phenomenon of terrorism is the question of what leads one or another person to a terrorist organization; why some prefer to leave career and development in ordinary society for the sake of the often life-threatening membership of an illegal group calling for violence (Golyandina, Ardavov \& Mashekuasheva, 2014).

The main premise is that terrorism will be best understood through the prism of the psychological interpretation of material conditions and the ability to overcome seeming injustice, especially injustice in decision-making processes. Researchers interested in the deep motivation of terrorists point to the great importance of the positive attractiveness of the feeling of belonging to a secret powerful organization, contributing to the successful solution of the problem of self-identification while maintaining the highest level of self-esteem.

Thus, the main task of countering the informational and psychological impact on young people in modern conditions is the implementation of a set of measures aimed at minimizing harmful propaganda and psychological effects, achieving moral and psychological stability, and readiness for resistance (Tarchokov, 2015).

The issue of involving young people in terrorist and extremist organizations is extremely relevant in the current situation with the anti-constitutional activities of informal youth groups of extremist-nationalistic orientation, which leads to the need to increase the targeted work on prevention, eradication of the causes and conditions causing extremism and terrorism among youth (Kotlyarova, Shubina \& Sysoeva, 2016).

However, the concern is caused not only by numerous recruiters, but also by the growth of crimes of a terrorist and extremist nature. If in 2012 in Russia there were about 700 such crimes, in 2015 it was already more than a thousand. The courts of the Russian Federation banned the activities of more than 20 terrorist and more than 40 extremist organizations (Prevention of youth involvement in terrorist and extremist organizations).

At the moment of significant upheavals and fractures, periodically arising in the process of development of any society and associated with the implementation of deformations of conditions and lifestyles of people, suddenly forming a vacuum of values, changes in material indicators, uncertainty of life prospects and the inevitable aggravation of contradictions, extremism, including religious, becomes one of the most dangerous negative characteristics of the socio-political process (Olifirenko, 2012: 7).

The spread of extremist and terrorist organizations in Russia has become one of the most acute problems. There 
remains a high level of crimes of an extremist and terrorist nature. The development of religious extremism among young people is particularly dangerous not only because child crime, adolescence and youth crime have increased significantly, but because it is connected with the development of "abnormal" attitudes in the group consciousness of the young generation, which affects values, preferred behaviors, and social assessments.

Studying the issue of involving young people in terrorist and extremist organizations, the researchers argue that it is impossible to say that a person has certain qualities that contribute to their entry into terrorist and extremist organizations, but do not deny the presence of a certain set of personal characteristics, coupled with certain social conditions, combining which may affect the choice of a person to participate in terrorist activities.

Each of us wants to achieve certain heights, to become famous. However, not everyone understands that for this it is necessary to work a lot and tirelessly: to go to school, in higher education, to work in good faith, bringing benefit to the people and the state. In any state there are always those who do not want to work not only for the good of their people, but even for their own well-being. But one should not think that it is only their fault, often such children or teenagers simply do not find understanding among their loved ones or are often exposed to domestic violence.

Another category of people prone to commit terrorist acts are those who are freely suggestible. Most often, such young people join the ranks of religious terrorist organizations. They easily false faith. In fact, there is not a single religion in the world that would preach enmity between people, kill children and women in order to preserve its exclusiveness and "correctness" (Prevention of youth involvement in terrorist and extremist organizations; Staroseltsev \& Pelyukh, 2012).

The qualitative and quantitative composition of extremist organizations has changed dramatically over the past decade. Today, among the members of such organizations are young people from prosperous families, not only socially, but also economically, which are many examples in the North Caucasus. In addition, it was believed that extremist organizations are young people with little education, or no education at all, however, practice shows that today there are young people in extremist organizations who have a university degree in law, and many are masters of sports (Mazdogova, 2014:20).

The state effective policy of protecting individuals, society, and especially its youth, most susceptible to the influence of a different spectrum of ideological attitudes from extremism, should include, first of all, a conceptual understanding of this phenomenon, its varieties and prospects for eradication. In this connection, the theoretical development of a set of problems related to the specifics of youth political extremism, the depth of its impact on the main components of the Russian socio-political system and the ability to reliably predict the direction of influence, as well as the forms of manifestation of extremism at its various levels, seems very relevant. Solving these problems will allow realizing the purely practical tasks of ensuring effective political governance and choosing the best ways to counteract negative social and political phenomena (Skuratov, Glazkova, Grudinin, Neznamova, 2016; Grudinin, 2016).

In his article "Religious extremism among the youth of Russia," the authors of V.P. Galitskiy and I V. Starshinov pay special attention to macrosocial factors contributing to the spread of extremism among young people. So they stand out: structural, situational, environmental and family factors (Galitskiy, 2010).

Among which there are:

- the presence of extreme social polarization in society and in the youth environment, and increased alienation and hostility between social groups;

- strengthening of migration processes, which are predominantly ethnic in nature;

- facts of inter-ethnic clashes in society;

- activity of the "extremist core" of youth;

- miscalculations in the ethnic, migration, and anti-extremist policies of the state;

- Negative experience of interaction with representatives of other nations or denominations, as well as incompetence regarding the traditions and customs of other nations;

- pedagogical miscalculations in education and a low standard of living of the family (Galitskiy, 2010).

Of particular importance is the need to organize a system of preventive and preventive measures to prevent the emergence and growth of extremist sentiments among young people, primarily carried out through legal and moral education of young people on issues related to security threats caused by the spread of religious extremism. 
In his address to the participants of one of the numerous conferences devoted to the prevention of extremism and terrorism among young people, the head of the antiterrorist center of the CIS member states, police colonel General Andrei Novikov said: extremely harmful. We are talking about meaningful systemic actions, primarily of an explanatory counter-propaganda nature. Not only psychologists should conduct this work, but also the entire teaching staff directly in the context of curricula in public disciplines." (Varvara Karaulova syndrome).

It is necessary in all educational institutions to develop action plans to counter terrorism and religious extremism, conduct parental meetings, class hours, conversations, lectures, disputes with the invitation of law enforcement officials, aimed at explaining to young people the legal consequences for: participation in illegal activities of a terrorist and extremist nature; participation in informal youth groups antisocial and criminal sense (Dadova, 2014:121).

When holding mass events involving a large number of young people, special attention should be paid to minors and young people who find themselves in a difficult life situation, have committed offenses, and have suspended sentences and those who have served their sentence. Individual preventive work should be carried out with this category of persons.

An important direction in preventing the involvement of young people in terrorist and extremist organizations in Russia is also the training of teachers. The complex of measures for teachers may be systematized on the basis of already available theoretical material of scientific research. When conducting preventive work, emphasis should be placed on the elaboration of possible options for preventive actions (Mazdogova, 2016).

The topic of terrorism in the past few years has been the object of increased attention, both from representatives of social sciences, and from representatives of political elites and the general public. This was largely caused by the 2001 terrorist attacks in the United States and the events that followed, which clearly showed that modern terrorism is a serious and pressing problem because it carries a significant threat to both political and economic elites and ordinary citizens, and It also often causes irreparable damage to the functioning of the economy and state institutions.

However, the events that followed after " $9 / 11$ ", connected with the emergence and activity of the international terrorist organization "DAESH", once again exposed and actualized the existing problems of the Islamic and world community. At the same time, the surprisingly effective information and propaganda campaign "DAESH", which has recruited thousands of "jihadists" from all over the world, including new ones, has become an unexpected element of the events from Kazakhstan.

At the same time, it is necessary to designate that the identification of terrorism and extremism only with radical Islam is incorrect, since A rather wide spectrum of political ideologies (forcible change of constitutional order, violation of state sovereignty, forcible seizure of power, organization of armed rebellion and participation in it), national (incitement to racial, national and tribal strife) and religious (incitement of religious enmity or discord) of violence.

In particular, experts disagree on the time of the emergence of terrorism, as one of the forms of violent influence on decision-making by state bodies. Others equate any political assassination with terrorism, and thus its roots are relegated to ancient times, others consider terrorism to be a phenomenon of the end of the 20th century (Busnitskiy, 1994-1995).

It is believed that even for 340 years BC. Alexander the Great's father was killed in a terrorist attack (Korolev, 2008). As a classic example of a terrorist organization, some cite the Shiite sect of assassins (Khashashin), which functioned in the XI century. Terrorism acquired additional sad "glory" with the spread of revolutionary ideologies in Russia, Europe and then North America in the 1880 s, as well as the anti-colonial, national liberation movements of the 20th century (Korolev, 2008).

\section{Materials and Methods}

Many researchers of extremism note that the most fertile ground for extremism and terrorism is currently the youth environment, where the loud crimes of young extremists have caused a wide public response. This opinion is confirmed by the statistics of the Ministry of Internal Affairs-FSB, according to which more than 90 percent of the members of extremist organizations are young people under the age of 30 . They make up 80 percent of all extremist crimes that committed crimes, including all murders based on national, racial and religious hatred. Moreover, more than half of them are minors.

Experts note that the nature of youth extremism is determined by the social and group characteristics of the consciousness of young people, and the forms of manifestation are associated with the specifics of its social behavior (Kirsanov, Davydov, Zavalsky \& Skribtsova, 2014). But this does not mean that the root of evil must be 
seen in young people. As an independent social group, it is part of society and in its own way reflects the uniqueness of each stage of its development. Therefore, in order to successfully counteract youth extremism, it is necessary, first of all, to clearly distinguish its causes, rooted, among other things, in the imperfection of society itself and in the shortcomings of the state youth policy, as well as the forms of its manifestation that have social and group specifics.

In our opinion, the substantive areas of increasing the effectiveness of countering the ideology and practice of extremism among students are:

1) educational direction, which means the formation of a system for training specialists in the field of countering extremism;

2) the organizational direction, including the holding of scientific-practical conferences, seminars, round tables, competitions for the best works and materials of an anti-extremist nature, etc .;

3) information and analytical support for countering extremism, the result of which is the production of monographs, teaching aids, scientific articles, books, addresses, posters, social advertising, the creation of thematic videos, etc ;

4) propaganda support, consisting in timely delivery to the student audience of objective information on the results of countering extremism;

5) the direction of interethnic cultural communication, interfaith dialogue (Vorontsov, 2012, 18-19 October).

The current stage of terrorism, including religious terrorism, is associated with globalization, which began in the late 1970s (Fedortsev, 2007).

As a rule, persons involved in terrorist and extremist activities for the most part represent the most radical wing of broader anti-systemic protest movements:

1) Ethnonationalism and separatism (Chechens in Russia, Uygurs in China, Basques in Spain, Irish in Great Britain, Kurds in Turkey, the Arab-Israeli conflict in Palestine, etc.);

2) Left-radical ideology (anarchism, Bolshevism, Trotskyism, Maoism);

3) Right-wing ideology (neo-Nazism, neo-fascism, racism);

4) Radical Islamism (takfiro-jihadism, sometimes mixed with ethnonationalism).

The actualization of Islamist terrorism is connected with the crisis phenomena of the established international political system. Today, armed, informational, trade and cyberwarfare are raging in the world, significant geopolitical shifts and confrontations are underway. In this case, the main events occur around the Islamic world.

After the collapse of the USSR, the redistribution of spheres of influence in the Middle East began actively. In particular, the military presence of the US and Western coalition in Iraq and Afghanistan, the civil war in Libya, Syria and Yemen, the return to the region of Russia, and the confrontation between Turkey, Iran, Qatar and Saudi Arabia for leadership, is a breeding ground for terrorist and extremist the activity of radical Islamists and the emergence of such a phenomenon as "DAESH".

Kazakhstan has also become the focus of religious terrorism and extremism. Here, the echoes of armed conflicts in the Middle East are superimposed on the internal problems of the young state.

This is confirmed by the spread of radical ideas of Salafism ("ji" hadism", "takhirism") alien to the Kazakh society, which resulted in the events that had not been seen in Kazakhstan: a counter-terrorist operation in the villages of Shubarshi and Kenkiyak of the Temir district of the Aktobe region, explosions in the city of Atyrau and a terrorist attack in The city of Taraz in 2011, the counter-terrorist operation in the city of Kulsary of the Atyrau region in 2012, the terrorist attacks in the cities of Aktobe and Almaty in 2016 (Shibutov \& Abramov, 2012).

Unfortunately, the turbulent Muslim renaissance in Kazakhstan ran into many problems:

1) Ideological vacuum formed after the collapse of the Soviet state and the rejection of the communist ideology (lack of control of the religious field in the 90s and early 2000s, the penetration of the ideologies of Hizb ut-Tahrir, Tablighi Jamaat, and Wahhabism);

2) The slow development of Islamic religious institutions under the auspices of the Spiritual Administration of Muslims of Kazakhstan;

3) Availability of sources of Islamic radicalism near the borders of Kazakhstan (separatism in the Chechen Republic of Russia and XUAR of the People's Republic of China, civil war in Afghanistan and Tajikistan, 
terrorist organizations Imarat Kavkaz, Islamic Movement of Uzbekistan, Islamic Party of Turkestan, Taliban, etc.)

4) Active social stratification within the framework of a capitalist market economy.

In response to the challenges posed, Kazakhstan developed its own model of "survival" and strongly supports a unique religious policy based on interfaith harmony and moral and political support for the so-called "traditional" Islam represented by the Spiritual Administration of Muslims of Kazakhstan.

At the same time, "traditional" Islam is based on the Hanafi madhhab, historically developed for Central Asia, the "akyd" of Imam Maturudi. It promotes religious moderation, as well as the revival and respect for the history, culture and customs of the Kazakh people, supports technological progress. Under the auspices of the SAMK, an Islamic infrastructure is being built for the needs of Muslims (mosques, madrasas, universities, namazkhan, halal products, attempts to introduce Islamic banking, religious holidays at the state level, etc.).

However, at this stage, the emergence of an anti-systemic protest mood among practicing Muslims is associated with the following problems:

1) The contradiction of key Islamic political values with the surrounding secular political culture (in Islam there is no separation between spiritual and secular, religion permeates all areas of life). As a result, some Muslims refuse to follow the religious policy of the SAMK, which is directed by a secular state (including on the prohibition of wearing hijabs in schools, prohibiting namaz in government institutions, etc.)

2) The armed conflict in Syria, the active propaganda activities of ITO "DAESH" on the Internet network. Foreign ideologues, as well as local activists of Salafism, under the pretext of imposing the so-called believers on believers. "True" or "pure" Islam, in fact, are engaged in the hidden radicalization of Muslims, which results in various terrorist and extremist actions.

As already noted, an important factor in the involvement of citizens in terrorist and extremist activities is technological progress in the field of communications. Over the past decade, on the Internet platform, numerous mass media have appeared in the form of social networks, instant messengers, blogs, weblogs, video hosting sites, which have significantly simplified the communication of the population (Kozhevnikov, 2017).

As a result, "DAESH" through various media structures in order to form public opinion, introduce it into the public consciousness and activate mass practical activity carries out radical propaganda. In particular, for the period from September to December 2017 alone, at least 46 thousand Twitter accounts were counted, which published more than 5 million posts (Berger \& Morgan, 2015), while new accounts constantly appear. It is important to note that some "DAESH" materials are distinguished by a high professional level, for example, the movie "The Sound of Swords".

The propaganda machine "DAESH" increases the volume of information materials for the CIS countries, Russian is the third most frequently used language in the propaganda of "DAESH" after Arabic and English. For the countries of Central Asia, DAESH produces products in Kyrgyz, Kazakh, Uzbek and Tajik languages.

The "DAESH" centralized information structure includes the following divisions:

1) "Al-Furqan Institute for Media Production" - the main information bureau;

2) “Al-I'tisam Media Foundation" - video production studio;

3) "Al-Hayat Media Center" - materials in foreign languages for foreign consumers, in particular, Dabic magazine;

4) “Al-Ajnad Media Foundation" - distribution of Islamic songs (nashid), music and poetry;

5) "Furat Media" - materials for Russia and the former Soviet republics of Central Asia, as well as Southeast Asia.

On the Internet, "DAESH" distributes information through the social networks "Twitter", "Facebook", "YouTube" and "Instagram". At the same time, "DAESH" appeals to the religious feelings of Muslims (in particular, convincing them that the duty of a Muslim is to emigrate to "DAESH"), protest sentiments against power, a sense of social justice, adherence to adventure (convincing young men that military "jihad" is a matter of courageous people and is associated with adventure) (Analytical report "The Islamic State": a phenomenon, evolution, prospects, 2016).

Thus, through the skillful use of social networks, an idea is being promoted, easily accessible to the understanding of the audience and resistant to criticism from outside. It is necessary to actively fight against such propaganda, and mainly - at the expense of "good", "white" counter-propaganda. 


\section{Results and Discussion}

In addition to this propaganda, the practice of contactless recruitment has spread. For example, Kazakhstani militants who left for Syria through social networks (individual correspondence, or in private chat rooms) actively recruit their own kindred and friendly religious ties, urging them to move to Syria, or to commit terrorist acts at the place of residence, also organize funding channels for members of the "DAESH ". At the same time, they actively send propaganda videos, scenes of hostilities, photos of armed "jihadists", supported by theses from religious sources.

It should be noted that similar methods of propaganda and recruitment of a contactless nature are followed by followers of madhalism, as well as tablary, which attract students to study at their own theological educational institutions, or attend any fees and congresses with traveling abroad. However, unlike DAESH, they are not so aggressive and purposeful.

In addition, the classical recruitment option is a contact method, since often the main task of radical religious movements is the creation of groups, jamagats, communities living under Sharia law, and not according to the laws of a secular state. Groups turn into marginal closed cells, where there are their charismatic leaders. Their intermediate goal is to attract adherents, supporters as much as possible, and the ultimate goal is to engender and realize destructive ambitions by manipulating the minds of those involved, actively using some of the proclaimed Islamic laws, the Sharia.

Recruitment to their ranks is primarily subjected to a close kindred and friendly environment. At the same time, the most effective and most common techniques and methods for recruiting members in the DRT are as follows:

- "the strength of weak ties" (the so-called network approach in sociology), when, unlike strong ties (family, informal, personal), weak ties are most effective when recruiting adherents into the ranks of radical movements (for example, through friendly, friendly, compatriot, clan-tribal ties);

- phased religious re-socialization (according to the principle of religious knowledge - religious practices - the isolation and rejection of the principles, norms, values of traditional and secular society). A number of experts are inclined to believe that closed structures (for example, the penitentiary system) represent a special "favorable" environment for the dissemination of radical ideas.

One of the favorite forms of extremist emissaries is recruiting young people who are experiencing a life crisis or are in a spiritual quest. Objects of recruitment can be people who have an active life position, often studying in educational institutions, athletes, cultural and art workers who have certain social resources, symbolic and social capital, as well as having a certain status and weight in society, etc.

Recruiters actively use such intentions and needs of young people as an interest in religion, a desire to read namaz. At the same time, the target becomes the openness of a person for new religious knowledge and experience, which makes it possible to quietly recruit this person, misleading and theologically wrongly explaining to him the canons of Islam. This so-called "Radical" Islam gradually breaks critical thinking among young people and makes it possible later to use manipulations to carry out various illegal actions and statements that incite religious strife.

Special target audiences are young or middle-aged people, marginal groups who do not have clear ingrained values, attitudes, some core or root in matters of national education in the bosom of traditional Islam and religious socialization (for example, people from atheistic or nihilistic families, people from ethnically mixed marriages, urban strata, migrants in search of social networks in order to adapt to new living conditions).

The adherents of these groups are ordinary people, legally and religiously illiterate for the most part, who mistakenly take the wrong for the right. The ideology of these groups is cultivated by those who are at the head. Initially, everything is based on good intentions, as it were, to help Muslims. Subsequently, everything is perverted and used for mercenary purposes, the sad results of which are described above.

The following main goals of radical currents can be distinguished:

- the formation of religious communities/zhamagata living exclusively under the laws of Islamic law;

- destabilization of interethnic and interfaith relations, which is based on external economic and political interests;

- attempts to construct a discourse of a just socially oriented non-secular state;

- legitimization of the new pure / correct Islam by denying and rejecting traditional Islam, national values, customs, traditions, holidays (denying belief in aruahs; differences in the practice of religious practices and 
rituals (reading namaz), distrust of media institutions (the prerogative of media with religious content);

- distrust of the institutions of medicine and public health (the rejection of vaccination for religious reasons);

- refusal to celebrate national and state holidays as opposed to religious holidays.

Thus, protest sentiments among practicing Muslims, difficulties with integration in secular society, social problems, as well as the weak role and low image of the Spiritual Administration of Muslims of Kazakhstan in religious life, lead to alternative Islamic religious trends, usually with foreign roots.

Despite the countermeasures taken by the international community, the level of both global and regional terrorist threats remains high. The desire of international terrorist organizations to actively participate in the internal conflicts of sovereign states is noted, which contributes to the gradual erosion of the boundaries between international and domestic terrorism and enhances their influence on the socio-political situation in other countries. Among the factors that have a decisive influence on modern terrorist threats to the CIS states are the idea of creating a "world caliphate" promoted by the banned terrorist organization Islamic State (hereinafter ISIL), the growing informational propaganda and recruiting activities of other international terrorist organizations (hereinafter ITO) and religious extremist organizations (hereinafter - REO) in cyberspace, focused on destabilizing the situation in specific countries, as well as the return from "hot spots" to the countries of origin of terrorists who have experience of hostilities and are focused on conducting subversive work in the field, including countries of Europe and the CIS.

The targets of ISIL, Al-Qaida, and radical groups ideologically close to them are the Republic of Azerbaijan, the Republic of Armenia, the Republic of Kazakhstan, the Kyrgyz Republic, the Republic of Moldova, the Republic of Tajikistan, Turkmenistan, the Republic of Uzbekistan, and the Russian Federation. The ideologists of radical Salafism are trying to attract Russian-speaking citizens of the Russian Federation and other CIS countries to cooperation, actively recruiting work from representatives of marginalized groups of the population in these countries, among labor migrants going to work in the Russian Federation and Turkey, as well as among young people going abroad to study in large Muslim educational centers in Egypt, Turkey, the Gulf countries. In the CIS countries and, especially, in the states of Central Asia, a significant increase in Islamization and radicalization of the population is recorded. This is facilitated by the active recruitment of citizens into the ranks of terrorist organizations, primarily to participate in the military operations of Syria, Iraq and Afghanistan, as well as to conduct sabotage and terrorist activities directly in their places of residence. To achieve these goals, ITO recruiters use such forms and methods as inciting religious and national intolerance; ideological treatment of citizens, including remotely (via the Internet); creating a positive image of a terrorist; material interest; promotion of their own distorted interpretations of the norms of Islam and the principles of Sharia. Recruitment activities are at the heart of maintaining a high potential of logistics officers and are closely linked to their active advocacy activities, which allows building a system of recruiting new members at a qualitatively high level (Kochubey, Mareev, Smirnov \& Sutormina, 2018).

The structure of this ITO has a powerful media holding that produces a wide range of multimedia products (video films, campaign clips, audio recordings of sermons and nashidov, magazines, booklets, posters, etc.) (Sundiev, Smirnov \& Kostin, 2015).

\section{Conclusion}

All of the above accordingly dictates the need for the state to adequately respond to contemporary challenges and threats to national security and to build an effective system to counter religious extremism and terrorism. In turn, a special significance in the prevention of this evil is given to government agencies that implement confessional policies.

In Kazakhstan, in general, a set of preventive measures has been developed, which are not punitive (the use of the practice of toughening punishment), but more warning.

To date, the established advocacy groups (working under the coordination of akimats) are carrying out large-scale work to ensure religious freedom and prevent religious extremism among the population. Their goal is to provide the population with complete and reliable information on religious issues.

In addition, the SAMK is actively involved in the restoration of the spiritual foundations of our society, ensuring the development of the Muslim community in our country. The Muftiyat also regularly organizes scientific conferences and seminars on inter-religious dialogue.

Muftiyat conducts a great educational and educational activities, publishes newspapers and magazines. The website of the Spiritual Administration www.muftyat.kz is functioning on the Internet, as well as the website of 
the Hazret-Sultan mosque www.muslim.kz, which is located in Astana.

It should be noted that the state and the spiritual administration of Muslims are doing a lot of work to prevent religious extremism and terrorism not only among the youth, but also among the population as a whole. Undoubtedly, all these measures are bearing fruit, which allows sincerely hoping that Kazakhstan will continue to remain a place of unity and harmony for all Kazakhstanis, regardless of their religious and ethno-cultural affiliation.

\section{References}

Analytical report "The Islamic State": a phenomenon, evolution, prospects ", Moscow, MGIMO-University. (2016).

Berger, G., \& Morgan, G. (2015). The activities of the ISIL in "Twitter": the definition and classification of supporters of the ISIL in "Twitter". Washington.

Busnitskiy, O. V. (1994-1995). Terrorism: history and modernity. AYREKS.

Dadova, Z. I. (2014). Prevention of extremism in the youth environment on the example of the Kabardino-Balkaria. Teoriya i praktika obshchestvennogo razvitiya, (14), 124-127.

Fedortsev, V. A. (2007). Non-state terrorism as a form of political struggle. Moscow.

Galitskiy, V. P. (2010). Religious extremism among the youth of Russia. Observer, (6), 16-18.

Golyandina, N. P., Ardavov, M. M., \& Mashekuasheva, M. H. (2014). Interaction of Internal Affairs with representatives of religious denominations. Theory and practice of social development, (16), 127-131.

Grudinin, N. S. (2016). The identity of a minor Russian criminal and the mechanism of its formation. Scientific Herald, 2(8), 20-27.

Kardan, R. R. (2014). Role of forensic expertise in anti-terrorist activities. Reports of the Adyghe (Circassian) International Academy of Sciences. Vol. 16. No. 1. 92-96.

Kirsanov, A. I., Davydov, D. G., Zavalsky, A. V., \& Skribtsova, N. A. (2014). Characteristics of extremism in the youth environment and its prevention in an educational organization (according to the results of an expert survey). Psychological Science and Education, (1). https://doi.org/10.17759/psyedu.2014060111

Kochubey, M. A., Mareev, P., Smirnov, A. A., \& Sutormina, E. V. (2018). Prevention of terrorism and extremism in the youth environment. St. Petersburg: Rus.

Korolev, A. A. (2008). Terror and terrorism in the psychological and ideological dimension: history and modernity. Moscow State Humanitarian University.

Kotlyarova, V. V., Shubina, M. M., \& Sysoeva, O. N. (2016). Youth extremism in social networks: specificity and theoretical understanding. Bulletin of the higher school Alma mater, (5). https://doi.org/10.20339/AM.05-16.095

Kozhevnikov, K. J. (2017). Internet is a one of ways to involve people in extremist activity. Nauka.

Mazdogova, Z. Z. (2014). Prevention of extremism in the field of interethnic and interfaith relations. Urist-Pravoved, (4), 20.

Mazdogova, Z. Z. (2016). Prevention of youth involvement in terrorist and extremist organizations. Problemy ekonomiki i yuridicheskoy praktiki, (5), 227-229.

Olifirenko, E. P. (2012). Youth Religious Extremism in Modern Russia and Ways to Overcome It (on the North-Caucasian Federal District). Krasnodar.

Prevention of youth involvement in terrorist and extremist organizations. Retrieved from http://chess39.ru/uploads/2016/ATK\%20K\%200\%20\%20-\%20ATTS\%20SNG.pdf

Shhagapsoev, Z. L., \& Tarchokov, B. A. (2012). The modern contours of countering the various manifestations of terrorism. Nalchik: SRS(f) Crewe Russian Interior Ministry.

Shibutov, M., \& Abramov, V. (2012). Terrorism in Kazakhstan - period of 2011-2012. Almaty.

Skuratov, Yu. I., Glazkova, L. V., Grudinin, N. S., \& Neznamova, A. A. (2016). The development of organized crime in Russia: a system analysis. All-Russian Journal of Criminology, 10(4), 638-648. https://doi.org/10.17150/2500-4255.2016.10(4).638-648

Staroseltsev, M. M., \& Pelyukh, E. I. (2012). Religious extremism: Interpretation of the concept? Bulletin of the 
Belgorod Law Institute of the Ministry of Internal Affairs of Russia, (2).

Sundiev, I. U., Smirnov, A. A., \& Kostin, V. N. (2015). Outreach activities of the Islamic State of Iraq and the Levant terrorist organization. Biblioteka kriminalista, (1), 208-218.

Tarchokov, B. A. (2014). Criminological characteristics of reasons for the spread of youth extremism. Gaps in Russian legislation, (3), 271274.

Tarchokov, B. A. (2015). Motivational features of involving youth in terrorist activities. Istoricheskaya $i$ sotsial'no-obrazovatel'naya mysl', 7(6-1), 211-213. https://doi.org/10.17748/2075-9908-2015-7-6/1-211-213

Tarchokov, B. A., \& Shhagapsoev, Z. L. (2014). Technology manipulation effects used by terrorist organizations in recruiting activities. Theory and Practice of Community Development, (14), 100-102.

Varvara Karaulova syndrome. Retrieved from http://rv-ryazan.ru/news/46209.html

Vorontsov, S. A. (2012, 18-19 October). On the directions of countering the involvement of students in extremist and terrorist activities. Proceedings from All-Russian Scientific and Practical Conference. Moscow.

\section{Copyrights}

Copyright for this article is retained by the author(s), with first publication rights granted to the journal.

This is an open-access article distributed under the terms and conditions of the Creative Commons Attribution license (http://creativecommons.org/licenses/by/4.0/). 